\title{
Contractual Savings in Countries with a Small Financial Sector
}

\author{
Gregorio Impavido \\ Alberto R. Musalem \\ Dimitri Vittas
}

The World Bank

Financial Sector Development Department

May 2002 


\begin{abstract}
Countries with small financial systems are generally small economies with a reduced dimension of institutional relationships, a greater concentration of wealth, and a relatively less independent civil service. These characteristics facilitate concentration of functions and, more generally, weak governance. Only small economies with a relatively high level of per capita income,
\end{abstract}

minimum core of sound banks and insurance companies, sound and credible macroeconomic policies, and open capital accounts can benefit from the development of contractual savings. This can increase the options to obtain sound coverage against contingencies, increase the supply of long term savings, promote financial deepening, and improve financial risk management.

This paper-a product of the Financial Sector Development Department-is part of a larger effort in the department to study the effects of contractual savings on financial markets. Copies of the paper are available free from the World Bank, $1818 \mathrm{H}$ Street NW, Washington, DC 20433. Please contact Patricia Braxton, room MC9-704, telephone 202-473-2720, fax 202-522-7105, email address pbraxton@worldbank.org. Policy Research Working Papers are also posted on the Web at http://econ.worldbank.org. The authors may be contacted at gimpavido@worldbank.org, amusalem@worldbank.org, or dvittas@worldbank.org. May 2002. (30 pages)

The Policy Research Working Paper Series disseminates the findings of work in progress to encourage the exchange of ideas about development issues. An objective of the series is to get the findings out quickly, even if the presentations are less than fully polished. The papers carry the names of the authors and should be cited accordingly. The findings, interpretations, and conclusions expressed in this paper are entirely those of the authors. They do not necessarily represent the view of the World Bank, its Executive Directors, or the countries they represent. 


\title{
Contractual Savings in Countries with a Small Financial Sector
}

\author{
Gregorio Impavido, Alberto R. Musalem, and Dimitri Vittas ${ }^{\dagger}$
}

\author{
The World Bank
}

JEL Classification Code: G18, G23, G28.

Keywords: Contractual savings, Small financial systems, Private pensions provision.

\footnotetext{
${ }^{\dagger}$ Gregorio Impavido (gimpavido@worldbank.org), Alberto Roque Musalem, (amusalem@worldbank.org), and Dimitri Vittas (dvittas@worldbank.org) are Financial Economist, Advisor and Senior Advisor, respectively, in the Financial Sector Development Department of the World Bank. The authors are grateful to Giovanni Majnoni, Roberto Rocha and participants to the World Bank seminar on small financial systems for useful comments.
} 



\section{INTRODUCTION}

At present, $49 \%$ and $32 \%$ of the world workforce (approximately $800 \mathrm{~m}$ ) is covered by mandatory, publicly managed defined benefit (DB) pay-as-you-go (PAYG) and partially funded schemes, respectively. The rest of the workforce is covered by a mix of public $\mathrm{DB}$ and private defined contribution (DC). Only $10-15 \%$ of it is covered by public and/or private DC schemes. In mature economies with flat demographic pyramids like Poland, Italy and Slovenia, universal coverage is norm, public pension spending can reach $15 \%$ of GDP, and gross implicit pension debt can be as high as $400 \%$ of GDP. Ageing of population is bound to increase pressure on countries to reform their pension systems and so far, at least 12 countries have adopted radical reforms and some other 20 countries are in the process of formulating serious reform proposals.

The alternatives of allowing for massive immigration and/or delaying considerably the compulsory retirement age, or to reduce benefits or increase contributions to maintain/improve the financial viability of unfunded schemes are not politically feasible and this will encourage increased funding of pension liabilities in the future. The trends that emerge from the recent wave of reforms are: i) more funding of current liabilities; ii) more private management of assets; iii) more DC schemes; and iv) more individual responsibility and choice.

This paper heavily draws on work carried out in the Financial Sector Development Department of the World Bank studying the impact of contractual savings (pensions and life insurance) institution development on financial markets ${ }^{1}$ and related work carried out within the Financial Sector Vice Presidency of the World Bank ${ }^{2}$. The value added of this paper is in the identification of policy options and possible sequencing for the successful development of contractual savings in countries with small financial markets. The development of contractual savings is associated here to the development of a funded pensions pillar. No specific position is here taken on the issue of public and private sector participation in the provision of pensions or on the design details of the private component.

The paper is organized in the following way. Section I discusses the specificity of small financial systems. Section II discusses the minimum pre-requisites for the successful development of contractual savings. Section III discusses the likely benefits for the rest of the financial sector of the development of contractual savings in small financial systems. Section IV discusses the options available to policy makers in these countries to provide private pensions. Conclusions follow in Section V.

\section{WHAT CHARACTERIZES COUNTRIES WITH SMALL FINANCIAL SECTORS?}

Small financial sectors are usually found in small, open economies with small population. Table 1 lists 87 countries with M2 less than US\$ 5 billion, for which 1999 data was

\footnotetext{
' See Catalan et al. (2001), Impavido and Musalem (2000), Impavido et al. (2001a and 2001b), Vittas (1998a and1998b) and the papers there referenced.

${ }^{2}$ See Glaessner and Valdés-Prieto (1998) and Bossone et al. (2001).
} 
simultaneously available for M2, GDP, population, imports of goods and services and export of goods and services

Table 1: Countries with small financial sectors, 1999

\begin{tabular}{|c|c|c|c|c|c|c|}
\hline $\begin{array}{l}\because \\
\therefore\end{array}$ & $\begin{array}{c}\text { M2 } \\
\text { (USs } \\
000000)\end{array}$ & $\begin{array}{c}\text { GDP } \\
\text { (USS } \\
000000)\end{array}$ & $\begin{array}{c}\text { Per capita } \\
\text { GDP } \\
\text { (US\$) }\end{array}$ & $\begin{array}{c}\text { Population } \\
(000)\end{array}$ & $\begin{array}{c}\text { Openness: } \\
(\mathrm{X}+\mathrm{M}) / \mathrm{GDP}\end{array}$ & $\begin{array}{l}\text { M2/GDP } \\
(\%)\end{array}$ \\
\hline Sao Tome and Principe & 11.46 & 46.40 & 319.44 & 145.26 & 119.31 & 24.71 \\
\hline Comoros & 40.49 & 209.10 & 384.18 & 544.28 & 66.74 & 19.36 \\
\hline Equatorial Guinea & 57.11 & 873.39 & $1,972.97$ & 442.68 & 188.21 & 6.54 \\
\hline Guinea-Bissau & 66.22 & 239.57 & 202.22 & $1,184.67$ & 69.57 & 27.64 \\
\hline Guinea & 71.74 & $1,280.36$ & 176.59 & $7,250.52$ & 44.88 & 5.60 \\
\hline Sierra Leone & 107.62 & 775.80 & 156.75 & $4,949.34$ & 34.13 & 13.87 \\
\hline Gambia, The & 129.03 & 415.50 & 332.14 & $1,251.00$ & 117.14 & 31.05 \\
\hline Mauritania & 135.47 & 968.08 & 372.58 & $2,598.33$ & 87.77 & 13.99 \\
\hline Niger & 150.34 & $2,162.50$ & 206.04 & $10,495.60$ & 38.35 & 6.95 \\
\hline Chad & 166.93 & $1,510.31$ & 201.76 & $7,485.61$ & 47.33 & 11.05 \\
\hline Burundi & 169.35 & 850.92 & 127.42 & $6,677.95$ & 27.09 & 19.90 \\
\hline Kyrgyz Republic & 169.74 & $1,429.68$ & 293.89 & $4,864.60$ & 99.20 & 11.87 \\
\hline Central African Republic & 175.96 & $1,107.98$ & 313.00 & $3,539.81$ & 40.90 & 15.88 \\
\hline Dominica & 195.96 & 278.49 & $3,814.89$ & 73.00 & 124.97 & 70.36 \\
\hline Bhutan & 196.60 & 500.80 & 640.62 & 781.75 & 75.00 & 39.26 \\
\hline Armenia & 204.56 & $1,965.31$ & 515.98 & $3,808.86$ & 70.67 & 10.41 \\
\hline Georgia & 220.77 & $2,961.94$ & 543.28 & $5,452.00$ & 73.01 & 7.45 \\
\hline St. Kitts and Nevis & 236.33 & 306.26 & $7,491.70$ & 40.88 & 118.14 & 77.17 \\
\hline Moldova & 239.64 & $1,365.33$ & 318.93 & $4,281.02$ & 114.82 & 17.55 \\
\hline St. Vincent and the Grenadines & 244.09 & 353.58 & $3,099.43$ & 114.08 & 122.76 & 69.03 \\
\hline Malawi & 271.60 & $2,022.20$ & 187.45 & $10,787.80$ & 69.63 & 13.43 \\
\hline Rwanda & 295.58 & $2,030.63$ & 244.36 & $8,310.00$ & 26.71 & -14.56 \\
\hline Grenada & 338.44 & 389.01 & $4,010.39$ & 97.00 & 125.40 & 87.00 \\
\hline Congo, Rep. & 342.49 & $2,417.89$ & 845.78 & $2,858.76$ & 148.43 & 14.16 \\
\hline Togo & 347.08 & $1,461.54$ & 320.03 & $4,566.94$ & 70.35 & 23.75 \\
\hline Cape Verde & 348.85 & 620.80 & $1,451.17$ & 427.79 & 73.51 & 56.19 \\
\hline Swaziland & 364.24 & $1,311.76$ & $1,286.71$ & $1,019.47$ & 205.20 & 27.77 \\
\hline Belize & 400.31 & 783.86 & $3,175.45$ & 246.85 & 107.26 & 51.07 \\
\hline St. Lucia & 453.94 & 680.14 & $4,410.78$ & 154.20 & 126.23 & 66.74 \\
\hline Guyana & 458.54 & 712.70 & 832.67 & 855.92 & 206.11 & 64.34 \\
\hline Turkmenistan & 490.86 & $3,641.08$ & 761.84 & $4,779.33$ & 103.53 & 13.48 \\
\hline Antigua and Barbuda & 512.96 & 669.80 & $9,933.25$ & 67.43 & 158.36 & 76.58 \\
\hline Azerbaijan & 529.93 & $4,390.58$ & 549.99 & $7,983.00$ & 84.45 & 12.07 \\
\hline Seychelles & 544.62 & 599.36 & $7,489.17$ & 80.03 & 159.36 & 90.87 \\
\hline Zambia & 585.38 & $3,533.03$ & 357.55 & $9,881.21$ & 63.11 & 16.57 \\
\hline Mali & 589.69 & $2,583.30$ & 244.08 & $10,583.70$ & 60.90 & 22.83 \\
\hline Burkina Faso & 593.33 & $2,612.71$ & 237.61 & $10,995.70$ & 40.71 & 22.71 \\
\hline Benin & 618.54 & $2,720.24$ & 444.92 & $6,114.05$ & 44.75 & 22.74 \\
\hline Macedonia, FYR & 661.51 & $3,904.75$ & $1,932.22$ & $2,020.86$ & 97.21 & 16.94 \\
\hline Gabon & 724.09 & $4,286.11$ & $3,546.90$ & $1,208.41$ & 83.47 & 16.89 \\
\hline Madagascar & 740.15 & $4,045.69$ & 268.81 & $15,050.50$ & 57.41 & 18.29 \\
\hline Fiji & 784.98 & $1,874.50$ & $2,340.19$ & 801.00 & 131.39 & 41.88 \\
\hline Uganda & 878.02 & $6,383.84$ & 297.21 & $21,479.30$ & 34.21 & 13.75 \\
\hline
\end{tabular}


Contractual Savings In Countries With A Small Financial Sector

\begin{tabular}{|c|c|c|c|c|c|c|}
\hline Country & $\begin{array}{c}\text { M2 } \\
\text { (US\$ } \\
000000)\end{array}$ & $\begin{array}{c}\text { GDP } \\
\text { (US\$ } \\
000000)\end{array}$ & $\begin{array}{c}\text { Per capita } \\
\text { GDP } \\
\text { (US\$) }\end{array}$ & $\begin{array}{l}\text { Population } \\
(000)\end{array}$ & $\begin{array}{l}\text { Openness } \\
(X+M) / G D P\end{array}$ & $\begin{array}{c}\text { M2/GDP } \\
(\%)\end{array}$ \\
\hline Mozambique & $1,013.01$ & $4,524.69$ & 261.56 & $17,299.00$ & 49.23 & 22.39 \\
\hline Senegal & $1,158.02$ & $5,045.08$ & 543.34 & $9,285.31$ & 71.81 & 22.95 \\
\hline Papua New Guinea & $1,160.11$ & $3,696.25$ & 785.66 & $4,704.62$ & 86.84 & 31.39 \\
\hline Zimbabwe & $1,226.72$ & $6,462.45$ & 542.89 & $11,903.70$ & 90.90 & 18.98 \\
\hline Cameroon & $1,371.07$ & $9,327.75$ & 634.95 & $14,690.50$ & 49.34 & 14.70 \\
\hline Namibia & $1,387.39$ & $3,333.21$ & $1,959.18$ & $1,701.33$ & 116.24 & 41.62 \\
\hline Haiti & $1,445.06$ & $4,745.99$ & 608.23 & $7,803.00$ & 40.10 & 30.45 \\
\hline Ghana & $1,451.95$ & $8,356.84$ & 444.88 & $18,784.50$ & 83.99 & 17.37 \\
\hline Nicaragua & $1,510.68$ & $2,462.86$ & 500.71 & $4,918.75$ & 122.28 & 61.34 \\
\hline Botswana & $1,563.07$ & $5,588.50$ & $3,518.94$ & $1,588.12$ & 60.58 & 27.97 \\
\hline Tanzania & $1,634.80$ & $9,504.03$ & 288.68 & $32,922.60$ & 41.32 & 17.20 \\
\hline Barbados & $1,667.87$ & $2,632.43$ & $9,871.13$ & 266.68 & 105.80 & 63.36 \\
\hline Estonia & $1,766.65$ & $5,697.99$ & $3,950.38$ & $1,442.39$ & 159.48 & 31.00 \\
\hline Latvia & $1,773.97$ & $6,506.79$ & $2,676.48$ & $2,431.10$ & 104.33 & 27.26 \\
\hline Albania & $2,127.02$ & $4,044.76$ & $1,198.36$ & $3,375.23$ & 41.26 & 52.59 \\
\hline Lithuania & $2,243.00$ & $11,029.97$ & $2,981.88$ & $3,699.00$ & 90.05 & 20.34 \\
\hline Kazakhstan & $2,291.44$ & $20,542.02$ & $1,376.17$ & $14,927.00$ & 85.31 & 11.15 \\
\hline Ethiopia & $2,392.45$ & $6,302.06$ & 100.38 & $62,782.00$ & 43.12 & 37.96 \\
\hline Yemen, Rep. & $2,408.90$ & $7,270.50$ & 426.48 & $17,047.60$ & 84.01 & 33.13 \\
\hline Nepal & $2,412.51$ & $5,458.67$ & 233.43 & $23,384.20$ & 52.98 & 44.20 \\
\hline Honduras & $2,452.62$ & $5,979.70$ & 946.51 & $6,317.65$ & 99.64 & 41.02 \\
\hline Paraguay & $2,512.10$ & $8,168.30$ & $1,524.27$ & $5,358.84$ & 59.70 & 30.75 \\
\hline Cote d'Ivoire & $2,721.67$ & $11,111.17$ & 714.75 & $15,545.50$ & 81.84 & 24.49 \\
\hline Iceland & $2,747.80$ & $8,180.17$ & $29,478.09$ & 277.50 & 71.98 & 33.59 \\
\hline Trinidad and Tobago & $3,349.43$ & $6,982.68$ & $5,401.42$ & $1,292.75$ & 93.43 & 47.97 \\
\hline Jamaica & $3,357.67$ & $7,491.04$ & $2,883.39$ & $2,598.00$ & $--107.42^{-}$ & -44.82 \\
\hline Mauritius & $3,448.51$ & $4,543.82$ & $3,869.06$ & $1,174.40$ & 132.67 & 75.89 \\
\hline Bulgaria & $3,765.03$ & $13,097.57$ & $1,595.71$ & $8,208.00$ & 96.03 & 28.75 \\
\hline Bolivia & $4,106.27$ & $8,593.43$ & $1,055.96$ & $8,138.00$ & 44.44 & 47.78 \\
\hline Guatemala & $4,217.05$ & $19,381.44$ & $1,747.90$ & $11,088.40$ & 46.38 & 21.76 \\
\hline Kenya & $4,668.15$ & $10,959.48$ & 372.64 & $29,410.00$ & 55.59 & 42.59 \\
\hline Costa Rica & $5,040.48$ & $16,691.72$ & $4,650.80$ & $3,589.00$ & 100.94 & 30.20 \\
\hline
\end{tabular}

Source: WBI

Table 2 reports the correlation among these variables for 1999. For this year, the correlation between the size of the financial sector (M2) and the size of the economy (GDP), openness (imports and exports over GDP), wealth (per capita GDP), and population ${ }^{3}$ was $0.94,-0.14,0.50$, and 0.30 , respectively. In other words, countries with small financial systems (M2) tend to have smaller and shallower financial markets, tend to be poorer, with smaller population, and more open ${ }^{4}$.

Small countries cannot fully exploit the economies of scale and scope in the provision of financial services. The reduced population limits the amount and quality of human

\footnotetext{
${ }^{3}$ From the contractual savings point of view the variable "labor force" would be more appropriate. We assume that a very high and significant correlation exists between total population and labor force.

${ }^{4}$ Although the correlation is significantly different from zero at only $12 \%$.
} 
capital they can draw upon. The lack of resources limits the scope for the development of the financial infrastructure like payment systems, organized markets, supervision, and regulation; sunk costs are simply too high for poorer countries. As a consequence, small financial markets are generally shallow, incomplete, poorly regulated, illiquid, prone to lack of competition and concentration in the provision of services, inefficient, and characterized by relatively high transaction costs. Small economies are more volatile: their median standard deviation of private consumption, terms of trade, inflation, GDP growth, and capital flows per GDP is between 1.5 and 4 times higher than in larger countries (Bossone et al. 2001). All this, in turn, impairs investment and hence, growth.

Table 2: Correlation matrix

\begin{tabular}{r|rrrrrr}
\hline & \multicolumn{1}{c}{ M2 } & GDP & $\begin{array}{r}\text { Per Capita } \\
\text { GDP }\end{array}$ & Population & Openness & M2/GDP \\
\cline { 2 - 7 }$p$-value & 1.0000 & & & & & \\
GDP & & & & & & \\
p-value & 0.9404 & 1.0000 & & & \\
[0.0000] & & & & & \\
Per capita GDP & 0.4992 & 0.4651 & 1.0000 & & & \\
p-value & {$[0.0000]$} & {$[0.0000]$} & & & & \\
Population & 0.3001 & 0.2664 & -0.0099 & 1.0000 & & \\
p-value & {$[0.0001]$} & {$[0.0012]$} & {$[0.9058]$} & & & \\
Openness & -0.1405 & -0.1919 & 0.1049 & -0.2098 & 1.0000 & \\
p-value & {$[0.1165]$} & {$[0.0313]$} & {$[0.2424]$} & {$[0.0105]$} & & \\
M2/GDP & 0.2719 & 0.1746 & 0.5516 & 0.2025 & 0.3671 & 1.0000 \\
p-value & {$[0.0009]$} & {$[0.0356]$} & {$[0.0000]$} & {$[0.0139]$} & {$[0.0000]$} & \\
\hline
\end{tabular}

Notes: The correlation coefficient was calculated over the pair-wise available observations within a sample of 158 countries.

Source: WBI and authors' calculations.

Despite the risks associated with openness, it is widely recognized that as trade openness can compensate for the underdevelopment of the real sector, financial liberalization allows to achieve the economies of scale and scope otherwise forbidden. This involves allowing foreign ownership of intermediaries, cross border financial transactions, participation in regional markets, the creation of regional infrastructure like regional organized markets, or regulatory and supervisory agencies, having sound and credible macroeconomic policies, opening of the capital accounts, and establishing exchange rate regimes that facilitate international integration. In a sense, small financial systems could integrate with larger systems as regions integrate within country.

In the next sections we discuss the financial preconditions for the successful development of contractual savings in small financial systems, the policy options available to policymakers for their development, and the likely externalities for the rest of the financial sector. 


\section{Preconditions for contractual savings DEVELOPMENT}

Clearly, if a fully-fledged and efficient financial system and institutions were a prerequisite for the successful development of private pension schemes, few countries in the world would be able to undertake systemic pension reform. However, the experience of countries in Latin America and Eastern Europe suggests that, unless reformers aim to begin with a nearly perfect system with low costs, high returns and highly diversified risk, an objective that would be both unnecessary and counter-productive, the practical preconditions are far less demanding. Instead of a fully-fledged financial system with a whole array of dynamically efficient institutions and the full range of financial instruments, what seems to be needed (Vittas 2000) are: i) a hard core of sound banks and insurance companies; ii) a long-term commitment by government to pursue financial sector reforms signaled, among other, by the implementation of sound macroeconomic policies; and iii) a long-term commitment for the creation of a sound regulatory and supervisory framework.

\section{II.A Sound banks and insurance companies}

Countries where the dominant banks and insurance companies are state-owned, financially insolvent and operationally inept are unlikely to succeed in their reform programs. Banks need to inspire confidence that they will be able to collect and transfer funds to their rightful owners, while insurance companies must be able to offer the basic insurance policies needed for a successful reform program. Funded pensions typically hold some bank assets, so weak banks threaten retirement income security (Mitchell 1998). Banks are also necessary (as providers of collateral, clearing, settlement etc. services) for security markets to grow and provide alternative pension fund investments. Nevertheless, the role of banks and insurance companies in the early years of pension reform can be easily exaggerated. The collection of contributions, their allocation to the accounts of their rightful owners, and the direction of accumulated funds to the selected asset management companies are parts of a major logistical exercise that requires considerable preparation and development of computerized systems, but it does not require fully developed banking and insurance sectors ${ }^{5}$.

Two aspects of the operation of pension funds are of crucial importance and may explain the insulation of pension funds from the adverse effects of widespread banking crises. The first is the effective segregation of pension fund assets from the assets of the management company and the financial group to which it belongs. And the second is the safe custody of pension fund assets. To ensure asset segregation, a country, small or large, needs a legal rule that mandates it and a pro-actively effective supervision to

\footnotetext{
${ }^{5}$ In Chile, the new pension system became operational in May 1981, but was not seriously affected by the collapse of the entire banking system in 1982-3. The pension funds placed their assets in government bonds and waited for the restoration of banking soundness before investing again some of their funds in bank deposits. In Argentina and Mexico, the gyrations of the banking systems did not have an adverse effect on the fledgling pension funds that were operated, more often than not, by subsidiaries of the same banks that faced serious financial problems. Banks in Eastern European countries, such as the Czech Republic and Hungary, have been in weak financial condition but this did not impede the implementation of systemic pension reform and creation of funded pension pillars.
} 
ensure compliance. Safe custody requires the presence of an institution with the financial, human and technical resources to fulfill this function. In the absence of sound and efficient local banks, two solutions suggest themselves. Either the central bank can perform this demanding function if it has the inclination and resources ${ }^{6}$. Or one or other of the global custodial banks, such as State Street, Northern Trust, Morgan Chase or Citigroup, can be invited to perform this function ${ }^{7}$. The development of central securities depositories and the concomitant dematerialization of marketable securities have made the offer of custodial services somewhat easier and more economical, but the issue remains an important one.

\section{II.B Long term government commitment}

Long-term government commitment is very important because pension reforms need to be accompanied by extensive reforms in fiscal and financial policies as well as capital and labor markets. While the absence of well-developed capital markets is not a major obstacle at the beginning of the pension reform program, mainly because the assets of the pension funds will be very small at first, capital market reform is a must in the long run as pension fund assets will continue to grow steadily over time. This is in fact one of the main characteristics of long-term contractual savings. Countries have between five and ten years to reform their capital markets and expand the range of available financial instruments, but unless they succeed in these reforms the funded pillar of the pension system will be unable to fulfill its fundamental objective, which is to contribute to the provision of better and more secure pensions to retiring workers.

The long term commitment of governments is signaled by the adoption of sound and credible macroecomic policies. Institutional investors cannot survive in high and volatile macroeconomic environment even if indexed instruments are used. Fiscal policies must be prudent. As long as the levels of nominal debt are too high, long term maturities are not attainable as the credibility of the antinflationary stance of the government is undermined (Missale and Blanchard 1994). Thus the beneficial impact from lengthening the maturity of debt to shield economies from financial crises may be undermined. Governments can always be tempted to devalue the currency at any given point in time. Finally, the use of contractual savings as captive sources of funding undermines the credibility of the monetary and fiscal policies. Expectations and risk premia do not decrease and debt managers are saddled with high long term interest rates.

Finally, the adoption of sound macroeconomic policies and the existence of sound banks and insurance companies would allow small countries to keep their capital account open and permit free trade of international financial services. As Kotlikoff (1999: 10) puts it "Indeed, there is ample evidence that the world capital market waits with bited breath to invest in those countries that have transparent and sound economic policies.

\footnotetext{
${ }^{6}$ In Chile, the central bank was the only authorized custodial institution for the pension system for at least the first ten years of its existence.

${ }^{7}$ Despite the importance of asset segregation and safe custody, it is important to note that few, if any, OECD countries impose sufficiently robust requirements for them. In Britain, the infamous Maxwell case, that occurred in the late 1980 s, has resulted in some tightening of the custodial rules, but neither there nor in any other leading country are there requirements for a strict segregation of assets and safe custody by a totally independent custodian. In this respect, Chile is still a leader among countries with funded pension pillars.
} 
There's also ample and very recent evidence that, at a moment's notice, global capital will flee developing countries that do not have such policies". This, as we will see, allows small countries to overcome many of the obstacle in developing contractual savings stemming from their small size.

\section{II.C Sound regulation and supervision}

Governments should finally be committed to the creation of a sound and robust supervisory and regulatory frameworks. This does not necessarily mean that a sophisticated supervisory authority or regulation be in place as preconditions for the development of contractual savings. As we will see in the next section regulation and supervision involve sunk costs and need developing together with the development of the institutions and if the country can afford not to rely on foreign specialization manage these functions locally. However, minimum regulation and supervision should be in place to ensuring that only qualified institutions obtain licenses, that contributions are paid in a timely manner, and that contractual terms are enforced. Over time, the regulatory agency could develop all its other functions, including the creation of a strong capability in undertaking off-site surveillance and conducting on-site inspections and contract out whatever function deems necessary.

In the next section we discuss the benefits linked to the development of contractual savings for small financial systems.

\section{BENEFITS FOR SMALL FINANCIAL SYSTEMS}

In general, small financial markets display different degrees of integration with the rest of the world and have different quality of macroeconomic policies, banking, and insurance sectors. This has an impact on their ability to benefit from the development of contractual savings. For the sake of exposition, small financial markets can be grouped in three categories: i) those that are incomplete but the segments that operate are sound, and are associated with high per capita income, credible macroeconomic policies, have open capital accounts (but domestic and international financial instruments are not perfect substitutes); ii) those that are incomplete but the segments that operate are predominantly unsound and stagnant, are associated with low per capita income, noncredible macroeconomic policies (due, for instance, to a long history of macroeconomic imbalances) and closed capital accounts; and iii) those that have intermediate positions between the previous two.

The first case of small incomplete and sound financial systems with relatively high per capita income, credible macroeconomic policies, and free capital movements (e.g., Iceland, Malta, and Cyprus) offer the best case for contractual savings development. Several reasons account for this: i) contractual savings is a luxury financial service which is demanded at high rather than at low per capita income (i.e., at high per capita income the time preference or discount rate is lower, thus increasing the valuation of purchasing coverage for future contingencies, also family ties could be weaker which reduce self insurance within the family); ii) credible macroeconomic policy provides an enabling environment for the development of long term financial instruments (e.g., contractual savings); iii) even under incomplete financial markets (e.g., embryonic capital markets), but where sound banks are operating, they provide a vehicle for channeling long term 
savings as long term loans to borrowers (government, enterprises, and individuals); and iv) open capital accounts do not constraint contractual saving institutions to invest in the local market.

There would be several benefits that could be obtained from the development of contractual savings in small incomplete and sound financial systems: i) it could increase the options to the population and enterprises to obtain sound coverage against contingencies (e.g., longevity, death, unemployment, severance payments); ii) it could increase the supply of long term savings thus promoting financial deepening and innovation, and improve financial risk management; iii) it may increase the national saving rate; iv) it could foster economic growth.

The development of contractual savings covering adequate regulations, supervision and tax treatment could provide the incentives for increasing the demand for these products beyond what could have been the case through off shore purchases of similar products. The higher demand could trigger the establishment of local companies as well as subsidiaries or branches of foreign providers. The location of the industry within the country may create opportunities for investments in the country rather than outside by increasing knowledge of the local investment markets. Also their presence may encourage the creation of domestic venture capital funds which could identify investment projects worth financing which otherwise would not had happened. Investments of contractual savings institutions based on the prudent investor rule would be composed of long term deposits in local and foreign banks, capital market instruments (government and corporate bonds, asset backed securities and shares) which most likely would be traded abroad, since the local market would be too small to develop a capital market, and small equity investments in domestic and foreign venture capital funds, and in leasing companies.

-.. Mandatory contributions to contractual saving plans could increase the national saving rate if some members of the population do not have sufficient access to credit. Under these conditions, they would be forced to save more since they would not be able to smooth out their consumption over their life cycle. In addition, the national saving rate would increase if governments do not take these funds as captive source of finance. Contractual savings development would foster growth because it has the potential to increase national saving, hence investments. In addition, contractual savings institutions would require a lower liquidity and premia because of their long term liabilities, thus reducing the cost of capital which in turn would increase investments and foster growth. Furthermore, the development of contractual savings would reduce refinancing risks of borrowers (governments, enterprises and individuals) while funding contingent liabilities. Also banks would be able to lend long term while reducing their term transformation risks. The improvement in risk management would reduce the country risk premium and interest rates which will foster investments and growth. Finally, the development of contractual savings by increasing long term savings will flatten the term structure of interest rate thus encouraging the undertaking of longer maturity investment projects. Since they have a higher rate of return, would also foster economic growth.

The second type of countries, those with chronic macroeconomic imbalances and other limitations, as spelled out above, provide very little room for the development of contractual savings. Long term saving instruments cannot prosper in a macroeconomic 
environment with high and volatile inflation, and contractual savings are unaffordable at low per capita income. Furthermore, these countries financial systems are limited to banks and they are usually weak institutions. Although it would be possible to invest abroad, these countries by having weak domestic financial institutions should have closed capital accounts. Hence, before trying to develop these instruments, the authorities should focus on establishing a credible long term macroeconomic framework and to strengthen banks prudential regulation and supervision.

In the intermediary category of small financial systems, there is a whole variety of cases. Let us consider countries with a credible macroeconomic policy, a relatively sound banking system, and an open capital account (e.g., Bulgaria, Costa Rica, Botswana). However, with incomplete financial markets (underdeveloped securities markets, insurance, mortgages), and low to medium per capita income. These countries have the preconditions for developing contractual savings, although the low to medium per capita income will constrain activity. Initially, the portfolio of contractual savings intermediaries would show primarily government bonds and banks long term certificate of deposits. In addition, they could have small fractions in shares, and foreign securities, and possibly in leasing companies. Gradually, investment regulations should allow more diversified portfolios as financial markets develop, by allowing higher investments in shares, foreign securities, corporate bonds, asset backed securities, and a small share in venture capital companies.

Information on small on portfolio allocation of pension fund in small financial systems is not readily available. However, inference can be drawn from the experience of countries with larger financial system at present but that could be categorized as countries with small financial system when private pension planes were launched. Figure 1 reports the changes in the investment allocation in financial assets of the Chilean pension funds. As of 1997, pension funds had 7\% of financial assets in cash and deposits, $66 \%$ in bills and bonds, $24 \%$ in shares, and 3\% in other securities. Since inception in 1981, Chilean pension funds have gradually reduced their holdings in cash, deposits and debt, whilst they increased the proportion of assets in stocks since this type of investment was authorized. This is in part due to the relaxation of the investment regulation on specific assets. At the beginning of Chile's pension reform, the investment regulations allowed up to 100 percent in government securities, up to 60 percent in corporate bonds, and up to 70 percent in each of the following categories: mortgage-backed securities, letters of credit or fixed term deposits. As the market developed, regulations were relaxed to allow investments in shares ${ }^{8}$, mutual funds, real estate funds, venture capital funds, securitized credit funds, foreign securities and hedging instruments.

\footnotetext{
${ }^{8}$ Shares were first allowed in pension funds portfolios in 1985.
} 


\section{Figure 1: Portfolio allocation of Chilean pension funds}

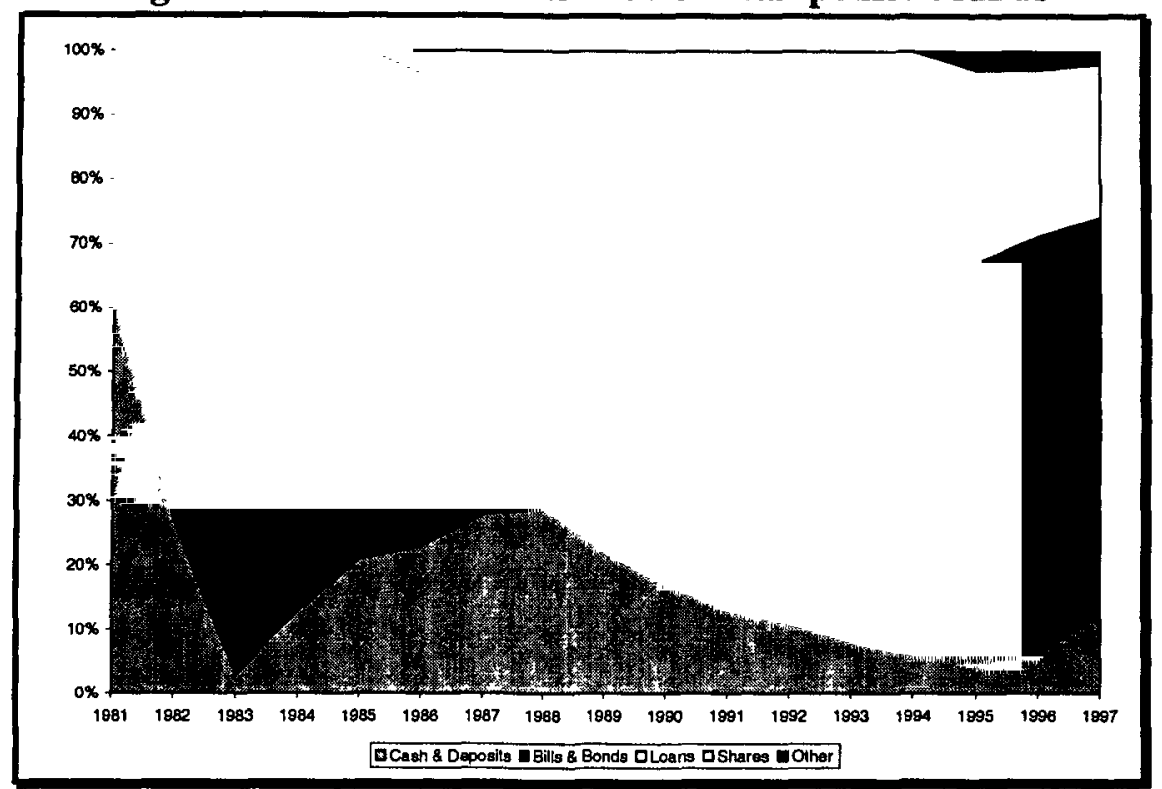

Source: WB contractual savings database

Notice that the increasing trend in the share of equities and bills and bonds in total portfolio is not necessarily a characteristics of small financial systems. Also countries with more established financial systems display the same trend. For the OECD countries Figure 2 shows how equities and bonds have increased in average from 20 and 31 percent, respectively to 33 and 38 percent respectively between 1982 and 1996.

Figure 2: Contractual savings portfolio allocation in OECD

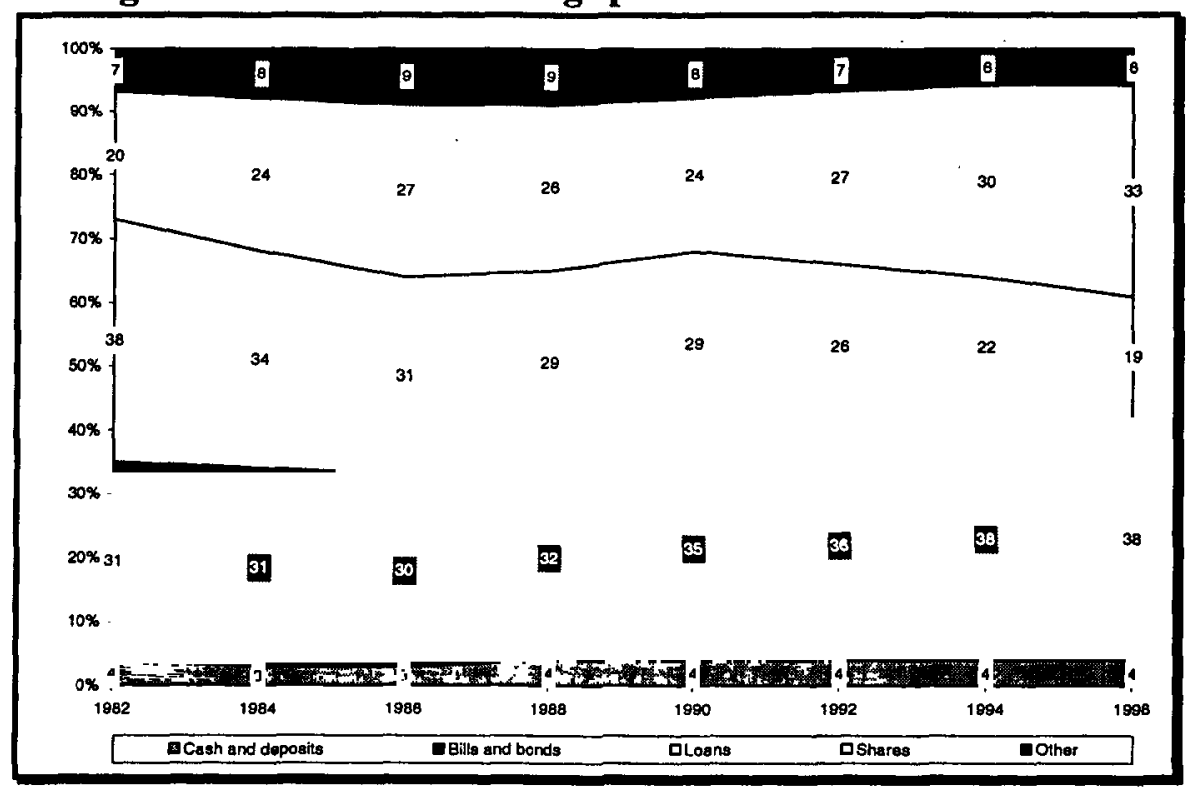

Source: 1998 OECD Institutional Investors Statistical Yearbook and WB institutional investors database. 
In summary, countries with a minimum core of sound banks and insurance companies, and with sound macroeconomic are highly likely to benefit from the development of contractual savings institutions. Gains from financial sector development will initially be concentrated in the development of the government bond market, and long term lending through banks. This would also help developing the sovereign yield curve which is a key ingredient for further capital market development. In a second stage benefits would come from the development of the equity and corporate bond markets, and asset backed securities, which in turn could benefit the development of housing.

In the next sections we discuss the policy options available to countries that meet the necessary preconditions for the development of contractual savings and that have small financial system.

\section{OPTIONS FOR CONTRACTUAL SAVINGS DEVELOPMENT}

Countries with small financial systems do not generally have a capital market of a viable scale. Their small scale often implies that these countries have very few sound and liquid assets where funds can be invested. They are characterized by a relative scarcity of human capital that generally leads to poor regulation and supervision. They have a relatively small population (and hence contributors) and a higher proportion of migrants engendering demographic instability. Finally, they usually have volatile economies, have greater concentration of wealth in the hands of few, and make greater reliance on patronage so that trustee services only rarely can be successfully provided.

What options have policymakers in developing contractual savings in this type of environment? For simplicity of exposition we discuss these options under three headings: i) alternative institutional set-up; ii) competition in the supply of pension services; and iii) fiduciary responsibility of pension fund managers.

\section{IV.AAlternative institutional set-ups}

An important question facing pension reformers concerns the institutional set-up of the new funded pillar. Should they authorize only one institution offering one fund to maximize economies of scale and ensure the same net returns for all workers, at least all workers of the same generation or cohort? Should the same institution offer a menu consisting of several funds allowing for contributors' choice? Should reformers authorize several institutions to encourage competition, innovation and efficiency, but at the risk of duplication of services and the higher costs involved with a smaller scale of operations? In the latter case, should they authorize specialized institutions with specialized funds or should they introduce special retirement accounts and allow all financial institutions to offer them?

Different countries have experimented with different approaches. On the one hand, the one fund approach has been evident in many countries in the form of a public fund, either a national provident fund operating a defined contribution plan or a partially funded social security corporation operating a defined benefit plan". The performance of the

\footnotetext{
${ }^{9}$ Among the former, the Central Provident Fund (CPF) of Singapore has an excellent operating record, although the investment returns offered to account holders have been very low. The funds collected by the $\mathrm{CPF}$ have been invested by other government agencies and the investment returns have probably been very
} 
social security organizations of Jordan and The Gambia has been acceptable, combining reasonably low operating costs with positive real investment returns ${ }^{10}$. However, the national provident funds of several African countries, as well as the social security organizations of Egypt and some Latin American countries, have suffered from disastrous financial results with highly negative real returns over long periods.

On the other hand, there is the proposal made by Larry Kotlikoff (1999). According to his idea all countries, especially those with underdeveloped financial systems, should hire a multinational financial group for the asset management of accumulated funds and require it to invest passively in a world indexed fund. A periodic bidding process would ensure a very low asset management fee, while use of the world index would maximize risk diversification and benefit from the high returns obtainable in equity markets. The Kotlikoff approach allows for age-specific portfolio allocations and has the advantage of avoiding massive marketing costs, while offering the same returns, at least to all workers of the same cohort. However, this approach has yet to be adopted by any country or even by any of the thousands of company pension plans in the United States and other AngloAmerican countries. While a growing number of large company pension plans opt for passive investment strategies, they tend to focus on national markets and have avoided allocating all their funds to a world index fund. This may reflect dissatisfaction with the construction of the world index or the well-known home bias that characterizes the operations of pension funds in most countries (Reisen 1995), but until some of the larger or more advanced countries were to adopt this solution, it is unlikely that smaller countries would do so ${ }^{11}$.

Most countries that have implemented systemic pension reforms, involving the creation of mandatory or voluntary funded pension pillars, have followed policies that fall between these extremes. Bolivia has organized an international bidding process for the award of a small number of licenses. After a protracted process it has selected two companies led by Spanish banks that satisfied the eligibility criteria (von Gersdorff 1997). The latter mainly emphasized international expertise in the operation of pension plans and individual accounts. It is interesting to note that the two Spanish groups that were

high, given the excellent economic record of Singaporean public corporations. However, the accounts of these corporations are not available for public scrutiny and little is known about their overall performance.

${ }^{10}$ The performance of the national provident funds in Malaysia and Sri Lanka have also been acceptable. If we look at the 1961 to 2000 period, the annual nominal dividend rate (Malaysia being an Islamic country does not have an interest rate concept ) was 7.04 percent with an annual inflation of 3.49 per cent. Hence, The Malaysian EPF has achieved a real dividend rate of of 3.55 percent, after all the management costs, investment management costs and so on. However, even this rate of return has been below the rate of increase in GDP. The nominal GDP has been increasing at 10.5 percent, the nominal dividend rate around 8 percent, so that the replacement rate is going to be relatively low.

11 Some countries have public pension funds that move in the direction of passive investment policies that resemble a world index approach. Norway, Ireland and Canada are the most prominent cases. However, in most of these countries, the public pension funds represent a fraction of accumulated assets. Moreover, the approaches are new and it remains to be seen to what extent they will be able to meet their objectives and resist political interference in their investment policies. The pension plan that comes closest to the Kotlikoff proposal is the Thrift Savings Plan instituted in the early 1980 s for employees of the federal government in the United States. This mandates use of three indexed funds (specializing in equities, bonds and money market instruments) and hires asset managers after an elaborate bidding process that contains extensive safeguards for ensuring an unbiased selection process. But even in this case, the plan does not mandate the use of a world index fund, but rather funds tracking US securities markets. 
awarded the two licenses, Banco Bilbao Vizcaya and Argentaria, later merged, creating a monopoly situation in the Bolivian pension market. This impasse was resolved by selling one of the pension funds to Zurich Finance. The Bolivian case underscores the important fact that institutional structures are not immutable $e^{12}$.

The size of the national market should be a determinant of the optimal number of independent pension funds in countries that opt for open, non-employer funds. For instance, among reforming countries, Colombia, El Salvador and Peru have authorized a small number of funds (Queisser 1997). Even so, subsequent mergers resulted in increased consolidation. El Salvador now has three funds and Peru five ${ }^{13}$. In Eastern Europe, Hungary started with a very large number of funds in its voluntary system. Even after consolidation, the voluntary pillar still numbers over 240 funds (Vittas 1995). The Czech Republic initially authorized 44 funds but their number has fallen to 20 . The Czech Republic is the only country where the liquidation of failed pension funds has resulted in financial losses for workers. However, the impact on workers has been mitigated by the fact that the losses have not exceeded the contributions paid by the government. In the compulsory pillars of Hungary, Poland and Kazakhstan the number of funds has been much smaller but it has been higher than the number of surviving funds in Latin American countries. This implies considerable scope for further consolidation in the pension systems of these countries ${ }^{14}$.

\footnotetext{
${ }^{12}$ If anything, institutional structures are always in a constant state of flux. In Chile, for instance, 13 companies, known as Administradoras de Fondos de Pensiones (AFP), were initially authorized when the system started in 1981 . Two of these companies merged very early on. The 12 companies that existed during the 1980s employed less than 3,000 agents and were able to recruit most of the workers that were required to participate in the system. After suffering large losses in the first five years of the new system, AFPs became highly profitable in the late 1980 s and attracted considerable now entry. The number of AFPs increased to 21 in the early 1990s. This led to a massive expansion in the number of selling agents from less than 3,000 in the 1980 s to over 15,000 by 1994 (Vittas 1995). New companies hired agents in an attempt to lure workers from existing AFPs, while existing companies were forced to fight back by expanding their sales forces. An undesirable result of the growth in the number of companies was a vast increase in marketing costs, that reached two-thirds of total operating costs and an explosion in the number of account switching. At its peak, the annual volume of account transfers involved one out of every two active accounts. Very few of the new companies were able to reach critical mass. Most withdrew from the market, either by being taken over by other AFPs or by closing down. The liquidation of a small number of companies proceeded smoothly without any financial losses for the workers that had accounts with the liquidated companies. The consolidation process that started in the early 1990s has progressed beyond its original starting point. There are now only 7 AFPs in the Chilean system.

${ }^{13}$ Argentina and Mexico started with a larger number of funds ( 25 and 17 respectively) but a wave of mergers has also reduced the number of funds in these countries as well. At the latest count, these stood at 13 in Argentina and 11 in Mexico. In Mexico, 11 pension funds administrators (AFORES) manage 13 funds (SIEFORES). I.e., 2 AFORES manage 2 SIEFORES each. It happens that the second SIEFORE targets voluntary contributors.

${ }^{14}$ In contrast to the countries of Latin America and Eastern Europe that have undertaken systemic pension reform in recent years, the pension systems of OECD countries with large private pension pillars are characterized by the presence of a plethora of employer-based pension funds. In the United States, there are over 700,000 funds and in the United Kingdom over 200,000. Australia reports well over 100,000 funds, although the vast majority of these are so-called "pop and mum" funds that cover owners of small firms and a select number of employees and are specially exempt from the regulatory rigors imposed on employer, industry and open funds. Switzerland has over 11,000 funds, but of these only about 4,000 have affiliated members and function like traditional funds. The remainder are funds without members, set as
} 
Employer funds incur lower marketing and operating costs because they do not need to engage in expensive advertising and pay high commissions to selling agents, and because their operating system can "piggy back" on the pre-existing company payroll system. Employer funds, unlike public funds, tend also to have a satisfactory level of investment performance, especially in countries that have not imposed quantitative restrictions but have relied on the so-called "prudent expert" approach (Davis 1999).

But workers covered by employer funds face different problems. If the fund operates a defined benefit plan, there are restrictions on eligibility, vesting and portability of pension rights (Vittas and Skully 1991), while the security of promised benefits depends on the continued solvency and integrity of the sponsoring employers (Bodie 1990). Initiatives to tighten the regulations covering these aspects of employer pension funds have resulted in an accelerated conversion of employer funds from defined benefit to defined contribution plans ${ }^{15}$. In the case of defined contribution plans, large employers tend to operate efficient funds or to negotiate with specialized financial institutions the offer of investment and other services on advantageous terms. But small employers tend to sponsor plans that incur high operating costs and/or low investment returns, either because small employers have weaker negotiating powers, or because they are offered advantageous terms on other types of financial services. Thus, the record of employer funds is more mixed than it may appear at first sight ${ }^{16}$.

Before concluding this section, mention should be made of the new Swedish approach that involves a public central agency for collecting contributions, maintaining individual account records and paying benefits with a decentralized asset management system. Workers have the right to direct their funds to several hundred authorized mutual funds. The latter receive the total funds allocated to them by workers but do not know the identity of their customers. This system of so-called "blind accounts" offers few incentives for direct selling; marketing expenses are limited to the creation of a brand name. Unlike Chile, the fee schedule is heavily regulated by the central agency (James et al. 1999). The system is highly complex and experienced considerable delay in its introduction. It depends for its success on the presence of a highly efficient central agency and a robust and effective regulation and supervision of the participating mutual funds. But it is a highly promising innovation that moves in the direction of regulated constrained choice.

This brief overview of the experience of different countries indicates that the institutional structure of the pension system depends on its basic design. Countries that rely on closed, employer-based funds tend to have a much larger number of funds than countries that rely on open, non-employer funds. Employer funds avoid marketing costs and enjoy some economies of scope (and scale for large employers), but their performance depends on the solvency and integrity of employers as sponsors of pension

financing vehicles often for "top hat" benefits or they are funds in the process of closing down (Queisser and Vittas 2000).

${ }^{15}$ This trend has been most pronounced in Australia, South Africa and New Zealand, but it is now spreading to other countries with a predominance of defined benefit plans.

${ }^{16}$ Unfortunately, the lack of timely, transparent and comprehensive data has impeded a thorough analysis of this issue even in countries, such as Canada, Switzerland, the United Kingdom and the United States, where employer pension funds have long been a dominant feature of the pension system. 
plans. The record seems to be positive for the pension funds of large employers, but rather mixed for the plans of smaller firms.

Countries that rely on open, non-employer funds tend to witness an inexorable consolidation process that results in the survival of a very small number of funds. A consolidated and highly concentrated pension system based on a small number of open funds enjoys economies of scale and may avoid excessive marketing costs. But such a system poses a serious policy challenge: how to ensure the continuing offer of competitive and efficient services. A solution could be to provide the opportunity to employers to opt out from the open end system by allowing employer-sponsored plans as well.

\section{IV.BCompetition in the supply of pension services}

Glaessner and Valdés-Prieto (1998) provide a framework to assess the role of State and private sector in providing pensions services in small developing countries. A similar approach used for utilities regulation is used to analyze pensions services. The authors disaggregate the supply of pensions services into elementary functions and discuss the extent to which policy makers would want to promote competition in the supply of any of these services.

As shown in Table 3, services like the collection of contributions, data processing, maintenance of records and accounts, channeling of funds to asset managers, and payment of benefits are likely to benefit from significant economies of scale (Glaessner and Valdés-Prieto 1998, James et al. 1999) ${ }^{17}$. The sunk costs associated with the provision of these services could be avoided by countries with small financial systems and little resources by attracting investments from highly reputable foreign companies. Glaessner and Valdés-Prieto (1998) also note that the small size of the market for pension services in small countries limits the interest of foreign direct investors in providing such services locally. The total revenues in terms of commission fees could be much less than 10 million US dollars per year in countries with less than 500,000 active contributors and

\footnotetext{
${ }^{17}$ This issue is addressed further below, but at this point it is important to note that several countries have tried to lower the operating costs of the funded pension pillar by mandating the use of a central agency. The cost benefits from using a centralized agency have long been argued by many commentators with attention drawn to the excellent operating record of the Central Provident Fund of Singapore (Vittas 1993). Several countries, including Argentina, Hungary, Kazakhstan and Poland, have tried to avoid the example of Chile and mandated the use of central collection agencies. However, almost all these countries made the serious mistake of assigning this important function to pre-existing public institutions with a long record of inefficiency and incompetence. The result, as exemplified by the experience of Poland and Kazakhstan, has been a long period of lost records, unaccounted money, misdirected funds, asset management companies that could not tell their customers where their money had gone, and workers that did not know if their employers had forwarded to the central agency the contributions witheld from their salaries. Mexico seems to be the only reforming country that has assigned this function to a central clearing agency jointlyowned by private sector institutions. Its record appears to be better than that of the public central agencies of Poland and other countries, but in Mexico the new agency built on the disastrous lessons of the previous, ill-fated program of 1992 (Cerda and Grandolini 1998). No other country seems to have come anywhere near the excellent operating record of Singapore. Yet the poor performance of the CPF in the investment returns offered to account holders has marred its record. On a net investment return basis, which is what ultimately counts for individual workers, the record of the CPF is far from enviable.
} 
wage rates of less than $\$ 500$ per month. In such cases, major foreign companies would have little interest in investing directly in setting up a local branch or agency.

Table 3: The supply of pensions services

\begin{tabular}{ll}
\hline \multicolumn{1}{c}{ Function } & \multicolumn{1}{c}{ Description } \\
\hline Collection of & $\begin{array}{l}\text { Collection of contributions } \\
\text { contributions }\end{array}$ \\
& $\begin{array}{l}\text { from employers and } \\
\text { distribution of the same to } \\
\text { fund managers }\end{array}$
\end{tabular}

Data processing Data entry control

Accounting and maintenance of records

Client services

Portiolio investment management

Insurance

Payment of benefits
Valuation of assets and liabilities for the fund or in individual accounts, reconciliation of accounts to produce updated balances Distribution of account statements, dealing with complaints, and answers to enquiries.

\section{Asset management (active or passive) and analysis of} investment opportunities.

Related to the provision of benefits

Calculation of benefits and transfer of cash to beneficiaries' accounts.
Economies of Scale/Scope

Economies of scope stem from three sources: i) employers have to fill different forms at different times for different collection services; ii) the cost borne by the employer decreases with the number of collection agencies; and iii) forms can be consolidated in a unique collection process.

Small countries with well functioning personal income taxation system may want to create a nationalized monopoly for the collection of contributors. Small countries with badly functioning personal income taxation system may want to create self regulated open capital company with shareholders including the entities benefiting from the collection services. (Mexico)

Economies of scope stem from the specialized know-how and technology linked to this function. However, costs from "data capture" are proportional to the number of participants and small countries would be better off by subcontracting this function to an external (offshore) entity. This is common for credit card data processing activity.

Economies of scale stem from the fixed costs of specialized hardware and software. Small countries with few contributors would not benefit from these economies and would be better off by subcontracting abroad this function.

Costs are usually proportional to the number of participants to the system and do not generate economies of scale. Small countries would only be constrained in the local development of this function by the excessive standards required by the regulation.

Not characterized by large sunk costs. The lack of financial expertise, illiquidity of the market, and concentration of interests in small countries could lead to price manipulation or conflict of interests. Small countries would be bettēr off by allowing foreign asset managers to take care of this function.

Small countries are characterized by limited pools and lack of asset diversification. For this reason, the provision of insurance benefits (disability, survivorship, or longevity insurance) should either be heavily reinsured abroad or simply provided by foreign companies through cross border services.

Economies of scale stem from the widespread geographic coverage. Small countries with poor distribution networks (banks or post offices) would be better off by centralizing this function. The option of a self regulated open capital company with shareholders including entities benefiting from the distribution of benefits seems to be the most suitable for smail countries.

Source: Glaessner and Valdés-Prieto (1998).

Whenever the small size of a country does not justify the sunk costs that characterizes some of the pensions services it might be necessary to allow foreign firms to centralize these services in a foreign location, where production costs could be lower and provided communication services are efficient and data privacy can be ensured. Several large 
financial groups already use shared local services in their operations in different countries $^{18}$.

Allowing for the subcontracting of services in the open market and for the use of crossborder providers would permit a more efficient unbundling of services and the emergence of greater competition in specific services, such as asset management, where economies of scale may be less dominant. In this way, the markets for the provision of pension services would become more contestable and would limit the potential adverse effects of the growing concentration of these markets. The rational for subcontracting arises especially since countries with small financial systems have small population and hence, likely to have a small pool of human capital with required expertise for an efficient operation of pension funds ${ }^{19}$. Many Latin American countries that reformed their pension systems, have allowed, even encouraged, foreign participation in their private pension pillar. In some cases, Chilean-style pension funds played a prominent part (e.g. in Peru and El Salvador). In other cases, foreign banks and insurance companies submitted applications in joint ventures with large local institutions ${ }^{20}$. In the Czech Republic and Hungary, foreign presence was not very large at the launch of the voluntary pillars in 1994. But in both Hungary and the Czech Republic there was a growing presence of foreign institutions over time. Foreign institutions now control more than 85 percent of the assets of pension funds in both countries. The growing foreign presence was linked to the consolidation of the banking and insurance sectors and the implementation of the privatization of large local institutions by sale to foreign strategic investors $^{21}$.

\footnotetext{
${ }^{18}$ For instance, the $I N G$ pension fund in the Czech Republic shares many services with the local subsidiary of Nationale Nederlanden, the insurance arm of $I N G$, while the investment of funds is subcontracted to the local ING asset management company. Using centralized services in another country would reduce operating costs, both because of greater economies of scale and because of the location of such centralized services in countries with lower labor costs.

${ }^{19}$ In Chile, at the beginning of the new system, no foreign companies were involved. As the rules did not allow the participation of banks, several of the early AFPs were set up by trade unions (despite the opposition of the government) and trade associations (the association of construction companies established Habitat, one of the most successful AFPs). Foreign companies entered the system in the early 1980s, probably in response to the early problems experienced by the new pension system. These included the adverse effects of the banking crisis of 1982-3, but especially the inability of local operators to maintain the high level of capital reserves that were initially required by the regulatory framework. Bankers Trust acquired a controlling stake in Provida (the largest company in the system), Aetna Insurance in Santa Maria and American International Group (AIG) in a joint venture with Bank of Boston (now part of Fleet Boston) in Union. Bankers Trust sold its stake in Provida at a big profit in the early 1990s, benefiting from its success, while $A I G$ and Fleet Boston withdrew from the market after failing to achieve a significant market share. Today, the AFP system is dominated by 2 Spanish banks (BBVA that has bought a controlling stake in Provida in recent years and BSCH in Summa Santander), an American bank (Citibank in Habitat), a Canadian insurance company (Sun Life in Cuprum) and an American insurance company (Aetna in Santa Maria).

${ }^{20}$ In Argentina, when the system was set up in 1994 the four or five largest Administradoras de Fondos de Jubilaciones y Pensiones (AFJP) were joint ventures of foreign and local institutions.

${ }^{21}$ When Hungary introduced its mandatory pillar in 1998, foreign banks and insurance companies held a dominant stake in the small number of mandatory funds that were authorized. Foreign institutions were also present in the establishment of the mandatory pillar of Poland. In Argentina, and more recently Mexico, the sale of large private banks and insurance companies to foreign strategic investors has resulted
} 
Reputable foreign institutions benefit from a number of operational advantages. They know how to operate efficiently systems with a large number of individual accounts. They have experience in cross selling and exploiting both economies of scale and scope. They have a well established expertise in asset management. And they are in a better position to resist government pressure and political interference in their day-to-day operations. They are also better able to integrate their local operations with their global activities and, by implication, with global markets. Finally, in their activity, foreign institutions train local staff and contribute to the improvement of the quality of skills.

It is worth noting that "the easy equation 'foreign equals good' is not always valid" (Bossone, et al. 2000). The authors make this comment in relation to the strategic investments of foreign banks in Hungary where not all of the purchasers were prime institutions and where some were suspected of laundering money. However, even in the absence of criminal activities, the record of foreign institutions is far from stellar. For instance, the performance of the pension funds owned by foreign institutions has been erratic, especially in Eastern Europe. Investment returns and operating fees have been unremarkable, the quality of service has left much to be desired, and the expected contribution toward creating a competitive and efficient system has been only partially met. Nevertheless, as in the case of banking and insurance, foreign pension funds have been able to operate with fewer problems, have not engaged in fraudulent or imprudent activities, and have taken steps to enhance further their operating and investment efficiency. The institutions that have devoted significant management resources and have placed local nationals in key management positions have performed better than those that have adopted a passive approach and have relied on expatriate management.

Countries with small and underdeveloped financial systems that engage in pension reform need to invite foreign banks, insurance companies and asset managers to play an active and central part in the establishment of the new private pillars. Ideally, foreign institutions should be encouraged to join forces with local groups, who know the local markets and can help them overcome any public opposition to the reform program. However, in the process of procuring financial expertise from abroad, small countries need to be particularly careful in allowing only highly reputable institutions to service their market. Highly reputable companies have also the incentive to perform up to expectation as their reputation costs are very high.

Moreover, by attracting reputable foreign companies, reforming countries would reduce the costs of supervision which may take time to develop to meet adequate standards. Reforming countries usually need also to enhance prudential regulation and supervision. Reputable foreign companies are usually domiciliated in developed market economy countries with a strong home country regulation. They could provide the host country with a transition period during which regulation and supervision are updated whilst effective regulation and supervision is carried out by the home country. In fact, it is more and more common for international regulators to share information about questionable international companies. In this framework the host country needs to

in a consolidation and expansion of the already significant presence of foreign banks and insurance companies in the pension system. 
develop strong links with the home country supervisory authority and sign memorandum of understanding for the exchange of information.

\section{IV.CThe fiduciary responsibility of pension fund managers}

Governments in developing countries often see contractual savings development as a captive source of finance for fiscal deficit or targeted industries. If not an alternative to debt monetization, these funds are often seen as a pool of funds for "developing" the economy. This forced development often means always two things: i) direct government control of asset management and direct investment into target industries, housing, and failing banks; and/or ii) prohibition of foreign investments by contractual savings. We discuss these two aspects in turn.

\section{IV.C.1 Trustee services}

State intervention in the allocation of pension funds is, unfortunately, the norm, rather than the exception in many developing countries. Public pension funds are regularly treated as captive source of funds and in many countries and this has seriously undermined the provision of old age pensions. Iglesias and Palacios (2000) survey the management of public pension schemes reserves. They find that "public pension funds are usually subject to a series of restrictions and mandates that produce poor returns. The non-pension objectives of the government often lead to social and economically targeted investments and forced loans to the government to finance its deficits. These investments yield returns that are often below bank deposit rates and almost always below the growth of incomes. This contrasts with privately-managed pension fund returns, which generally exceed income growth. The worst returns are produced by publicly-managed pension funds in countries with poor governance records".

Figure 3 summarizes the above statement by plotting the average real return on public pensions assets for 20 developing and developed countries against a governance index ${ }^{22}$. The relationship is highly non linear with rapidly diminishing marginal utility of governance. In other words, country like Uganda could improve considerably the rate of return on public pension assets with very limited governance improvement ${ }^{23}$.

\footnotetext{
${ }^{22}$ The index used is the governance index used in Mauro (1995) for all countries with the exception of Zambia, Uganda, Costa Rica, and Guatemala for which, the Corruption Index produced by Transparency International was used. Higher levels of the index indicate higher degrees of governance.

${ }^{23}$ Notice however, that the relationship presented does not imply causality but mere correlation.
} 
Figure 3: Pension annual real return and governance

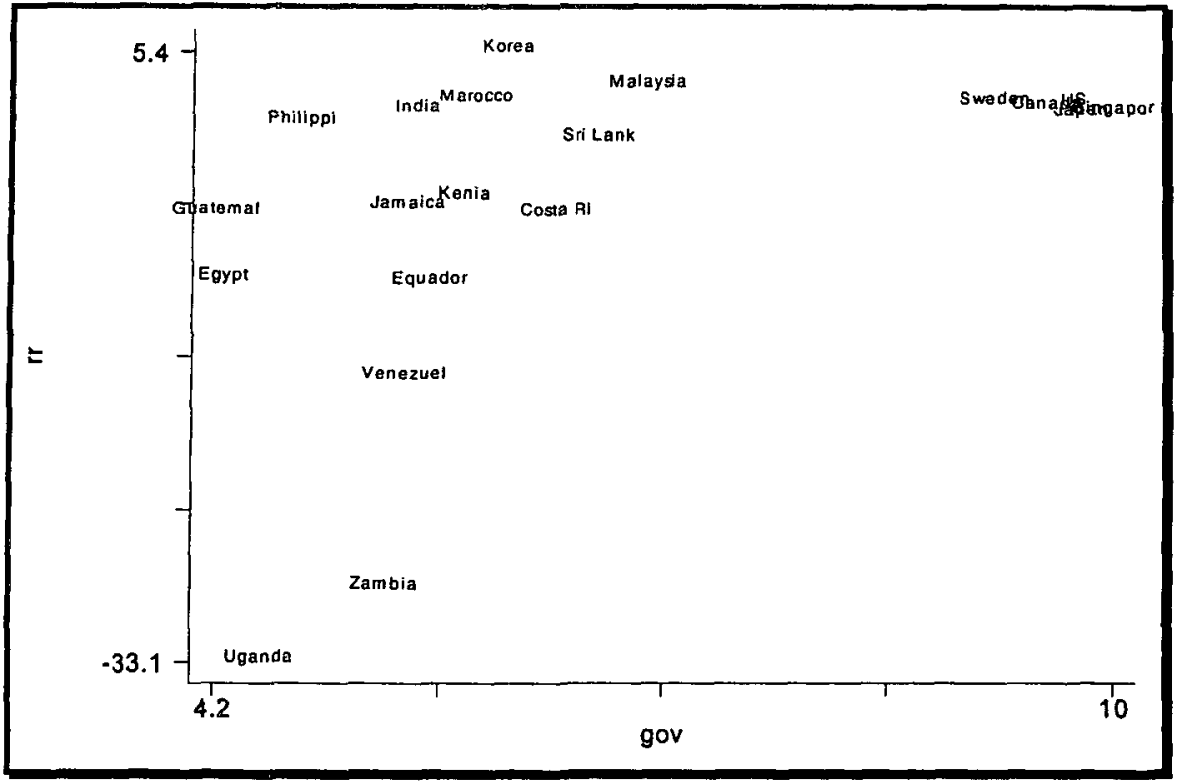

Source: Iglesias and Palacios (2000)

Table 4 presents summary statistics for the data used in Iglesias and Palacios (2000). In the first column of the table the correlation between the annual real rate of return and the governance index is 0.49 and significantly different from zero with a p-value of $2.7 \%$. This is the summary statistics of the relationship depicted in Figure 3. Similar results can be obtained by looking at the third column in the same table. The correlation between the standardized real rate of return of pensions assets and governance is now 0.38 and significantly different from zero at $10 \%$.

Figure 3: Pension annual real return and governance

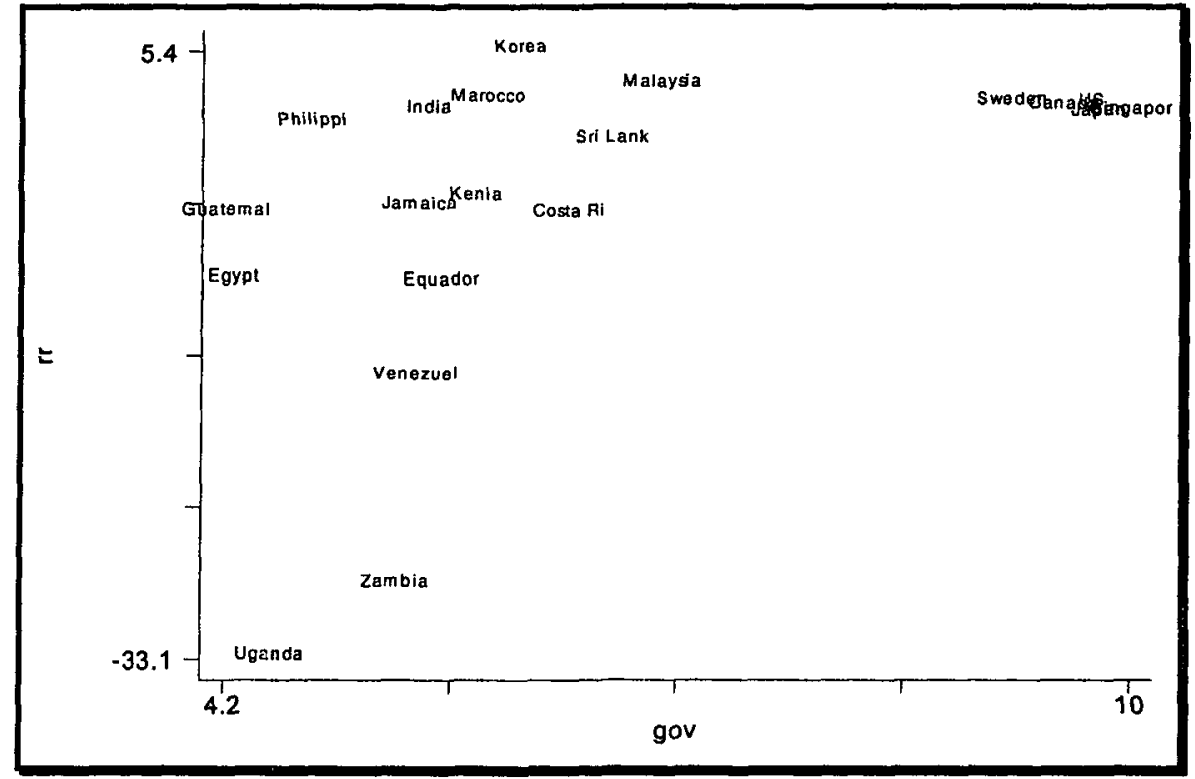

Source: Iglesias and Palacios (2000) 
Table 4: Pension annual real rate of return and governance

\begin{tabular}{|c|c|c|c|c|}
\hline Rate of return (RR) & $\frac{R R}{1.0000}$ & STD & RR/STD & Governance \\
\hline $\begin{array}{r}\text { Standard deviation (STD) } \\
\text { p-value }\end{array}$ & $\begin{array}{l}-0.8836 \\
{[0.0000]}\end{array}$ & 1.0000 & & \\
\hline $\begin{array}{r}\text { RR/STD } \\
p \text {-value }\end{array}$ & $\begin{array}{r}0.6746 \\
{[0.0006]}\end{array}$ & $\begin{array}{r}-0.5456 \\
{[0.0086]}\end{array}$ & 1.0000 & \\
\hline $\begin{array}{r}\text { Governance } \\
\text { p-value }\end{array}$ & $\begin{array}{r}0.4937 \\
{[0.0269]}\end{array}$ & $\begin{array}{r}-0.4664 \\
{[0.0382]}\end{array}$ & $\begin{array}{r}0.3787 \\
{[0.0997]}\end{array}$ & 1.0000 \\
\hline
\end{tabular}

Iglesias and Palacios (2000) use this data to compare the return of private pension with the return on public pension funds and inevitably find that public funds have been mismanaged in many countries and that private pensions are one way to introduce discipline in asset management. The interference of governments can be detrimental when investment policies are guided by objectives unrelated to the maximization of return on pensions assets. Low rates of returns on pension contributions induce distortions on the labor market as contributions are increasingly perceived as income tax. As a result, savings are not allocated to the most efficient use. Clearly governments want to overcome a situation of economic impasse by targeting key industries. However, the recourse to coercive regulation and captive source of funds is the short term answer to a credibility problem on the part of the government that prompts investors to impose high risk premia on future nominal interest rates ${ }^{24}$. What is not realized, or probably only underestimated, is that the use of captive source of funds only reinforce investors' expectations and seriously undermines the development of financial markets. When financial markets are not developed financial innovation is hampered and the cost of... capital remains high. Hence, efficient mobilization of savings and allocation of resources are denied. Furthermore, when these captive source of funds involve social security schemes, the provision of adequate pension benefits is undermined; and the implicit debt of the government inflated.

Specific recommendations can be made for small developing countries. In these countries the reduced dimension of institutional relationships, the relative scarcity of human capital, the greater concentration of wealth, and a relatively less independent civil service facilitate concentration of functions, interference by third parties and more generally weak governance. Glaessner and Valdés-Prieto (1996) argue that in the provision of pension services in small countries, it is essential that the supply of trustee services and governance be maximized. Not only is it important to procure, maybe abroad as previously mentioned, services from highly reputable companies, but it is as important to supply highly independent trustee services. These greatly influence the performance of pension funds by hiring and selecting asset managers, determining investment policies, selecting auditors, and asset custodians. The number of trustees per

\footnotetext{
${ }^{24}$ The US social security trust fund can only be invested in non-tradable government securities. However, the credibility of the macroeceonomic policy of the US government is not at stake and this exception to the reasoning before made can easily be explained in this way. Very different would be the situation if fiscal discipline in the US were non-existent as in many developing countries.
} 
pension fund should be high enough not to expose them to undue interferences. The number of trustees should be higher the larger is the share of the portfolio invested locally. As far as the selection of trustee is concerned Glaessner and Valdés-Prieto (1996) argue that in countries with weak governance structures, a pension system based on competitive selection of pension funds management companies by individual contributors can insulate the trustees from undue interference.

\section{IV.C.2 International investments}

Policy makers in small developing countries often look with suspicion at the option of liberalizing foreign investment by contractual savings. The economic literature looks at capital controls from the point of view that free intertemporal trade is welfare enhancing ${ }^{25}$. Hence, controls reduce social welfare but could be taken into consideration if their introduction mitigates the effects of some other market failure. Exchange controls are generally used in developing countries to protect the tax base and prevent "capital flight". Capital flows (inflows) are controlled to reduce moral hazard when the State maintains explicit or implicit guarantees for bank liabilities. Other market failures relate to sticky prices in goods and labor market, anticipated trade reforms, and short term private speculation ("hot money"). Small open economies are particularly exposed to the consequence deriving from capital mobility and in countries with weak financial systems capital flows are also controlled to reduce the possibility of financial crises. For instance, net capital inflows in the Asian crisis-affected countries went from 6.3\% of GDP in 1995 and 5.8\% in 1996 to $-2 \%$ in 1997 and 5.2\% in 1998 (Takaoshi and Kreuger 2001). Such deep swings can induce volatility of the real exchange rate. If authorities are interested in avoiding real exchange rate volatility, considered detrimental to export-led growth, they will try to sterilize these flows. In extreme cases only exchange control can prevent the exhaustion of foreign reserves.

In his survey, Dooley (1996) finds evidence that capital controls have been successful in maintaining interest differentials in both developed and developing countries. These controls have been used, together with other forms of financial repression, to increase net fiscal revenues (Aizenman and Guidotti 1994). However, the data does not support the idea that capital controls have been successful in affecting the volume and composition of private capital flows, changes in international reserves, the level of the exchange rate, or even effective in fending off speculative attacks in countries with inconsistent regimes or macroeconomic policies.

Whatever the rational of exchange controls, should they be applied to contractual savings? Fontaine (1997) surveys the Chilean experience in allowing foreign investment by pension funds. Only in March 1990 were pension funds allowed to invest abroad, almost 10 years after the pension reform. At that time, regulation allowed foreign investment of up to $3 \%$ of portfolio in fixed income securities issued by low risk countries and banks. In 1995 investment in foreign shares was allowed with a limit of

\footnotetext{
${ }^{25}$ The strand of the literature on multiple equilibria argues that capital control are a first best temporary solution enabling governments to increase their reputation and improve fundamentals so that self-fulfilling speculative attacks are less likely. The removal of controls can be seen by the market as a further commitment of governments in establishing even better reputation. See, and the list is not exhaustive, Obstfeld 1986a, 1986b, 1994, and 1996, Laban and Larrain 1997, and Bartolini and Drazen 1997.
} 
$12 \%$ of total portfolio. The paper concludes that there are no (good) macroeconomic reasons to treat international investment by pension funds differently from local ones. In other words, foreign investment by pension funds should be subject the same (mutatis mutandis) rules of diversification applied to domestic investments. However, Fontaine (1997: 269-270), argues that imposing restrictions on foreign investment by pension funds is desirable during the transition phase of a pension reform. This would serve the double purpose of: i) develop the domestic capital market; and ii) help the public sector ease the fiscal cost of transition between a PAYG and a fully funded scheme.

Restrictions on flows only should also be imposed during balance of payment crises and if asset stocks are large. This would limit volatility of capital flows and its impact on the real exchange rate (Davis 1999 and Fontaine 1997). However, restrictions on foreign investments would induce mispricing of domestic shares which is not the way to go to develop the domestic stock market. Despite a non well specified political economy rational for strict prudential regulation during the transition phase of a pension reform, the paper underestimates the risks involved in treating contractual savings as a captive source of finance. It is true that an efficient way to finance the cost of transition from a PAYG to a fully funded system would be to rely on the demand of government debt by pension funds. However, this strategy could undermine the credibility of the pension reform (hence, its success) should the government have weak credibility of respecting fiscal discipline. Unfortunately, governments have often relied on their powers of coercion to ensure sufficient demand for their debt to finance explosive expenditure, or of other targeted securities to finance well connected entrepreneurs. Sometimes it is the case that regulations require commercial banks to meet reserve requirements by holding government paper. Other times, and both in developing and in developed countries, commercial banks, insurance companies, pension funds, as well as social security funds, are required to invest in government bonds, sometimes in specially issued nonmarketable instruments with substantially below-market yields. Finally, many countries impose minimum quantitative floors of assets to be invested in government paper ${ }^{26}$ and politicians are often allowed to have a say in the investment policy of social security funds ${ }^{27}$. Obviously, these policies will increase the country risk premium and the cost of borrowing to the private sector, which may slow down the economy. The declining economic activity will ultimately reduce the government capacity to collect revenue and to service its debt.

The economic literature clearly supports free intertemporal trade as welfare enhancing. All rationales for introducing capital controls find limited support in the empirical literature. Their maintenance can greatly reduce the credibility of the macroeconomic

\footnotetext{
${ }^{26}$ Prior to 1986 , the Senegalese government forced commercial banks to invest a share of their assets in government bonds. After the collapse of the banking sector in 1986 regulation was relaxed. In the Philippines, the Social Security System (SSS) and the Government Service Insurance System (GSIS) are "offered" tax free government bonds that remain tax free to the extent that they are not subsequently traded. Hence forcing the two social security institutions to hold these assets until maturity. In Singapore, the Central Provident Fund is still required to invest a large share of its assets in non-marketable government securities; and only until recently this share was $100 \%$.

${ }^{27}$ In the Philippines, SSS and GSIS were often instructed to provide direct lending to industries to which commercial banks refused to lend. In Mexico as well as in the Philippines a large share of pension contributions needs investing in housing, INFONAVIT and Pag-IBIG, respectively. The real return of the assets of these "specialized" institutions have been rather disappointing.
} 
stance in countries with a poor record of economic discipline. Small open economies (and above all, developing economies) should allow foreign investment by contractual savings should the credibility of their macroeconomic policy allow it. In other words, only countries with credible macroeconomic policies should attempt developing contractual savings. A quantitative limit on the flow of foreign investment might be justified because of the vulnerability of a small financial system to excessive capital flow volatility. However, it is here taken for granted that some minimum needs to be invested abroad for diversification purposes and that flows can be limited to protect the balance of payments. Countries that need to impose foreign investment restrictions on the stock of contractual savings assets because of balance of payments concerns are countries with an unstable macroeconomic environment. These countries need first to stabilize their economies before attempting to develop contractual savings and hence their financial systems.

\section{CONCLUSIONS}

The development of contractual savings is strictly related to the implementation of a pension reform involving the establishment of funded pillars. However, no discussion is made here of system design issues that vary from country to country and are the result of various and diverse constraints. The conclusions we present here are summarized in Table 5.

Countries with small financial systems are generally small open economies with a high mobility of labor and a restricted pool of human capital. Apart from the demographic instability that this may engender, the short supply of human capital suggests that local financial expertise is also constrained. Moreover, the reduced dimension of institutional relationships, the greater concentration of wealth, and a relatively less independent civil service facilitate concentration of functions and more generally weak governance.

Not all countries with small financial systems are likely to be able to successfully develop contractual savings. Only countries with relatively high levels of per capita income are good candidates for a successful development of contractual savings. Moreover, a basic core of sound banks and insurance companies, as well as credible long commitment on the part of Governments to implement sound and transparent macroeconomic policies are also needed. 
Table 5: Contractual savings development options

\begin{tabular}{|c|c|}
\hline & Preconditions \\
\hline $\begin{array}{l}\text { - Relatively high } \\
\text { - Credible and tra } \\
\text { markets). } \\
\text { - Open capital ac } \\
\text { - Sound core of b } \\
\text { - Commitment to }\end{array}$ & $\begin{array}{l}\text { er-capita income (GDP/Pop >=US } \$ 2,000) \\
\text { Isparent macroeconomic policies and commitment to economic reforms (fiscal, financial, and labor } \\
\text { ount } \\
\text { inks and insurance companies } \\
\text { levelopment of sound regulatcry and supervisory frameworks. }\end{array}$ \\
\hline $\begin{array}{l}\text { Focus } \\
\text { areas }\end{array}$ & Policy options \\
\hline $\begin{array}{l}\text { Institutional set- } \\
\text { up }\end{array}$ & $\begin{array}{l}\text { - Allow bidding process among a limited number of open end funds. } \\
\text { - Allow funds to offer a menu of foreign mutual funds. } \\
\text { - Allow for employer sponsored funds. } \\
\text { - Require separation of assets from sponsor company. } \\
\text { - Allow small employers to contract scheme arrangements with larger funds. }\end{array}$ \\
\hline $\begin{array}{l}\text { Supply of } \\
\text { pension } \\
\text { services }\end{array}$ & $\begin{array}{l}\text { - Unbundle services into simpler components to be contracted out. } \\
\text { - Attract local investment from highly reputable companies in the services of: collection of } \\
\text { contributions, data processing, maintenance of records and accounts, channeling of funds to asset } \\
\text { managers, and payment of benefits. } \\
\text { - Subcontract same services abroad if small scale discourages foreign investments. }\end{array}$ \\
\hline $\begin{array}{l}\text { Fiduciary } \\
\text { responsibilities }\end{array}$ & $\begin{array}{l}\text { - Require the use of an appropriate number of trustees. } \\
\text { - Require the use of independent custodians (Central Bank or reputable Intermediaries). } \\
\text { - Allow foreign investments of assets. }\end{array}$ \\
\hline $\begin{array}{l}\text { Regulatory and } \\
\text { Supervisory } \\
\text { Costs }\end{array}$ & $\begin{array}{l}\text { - Develop at first minimum regulatory and supervisory capacity focusing on high standards (information } \\
\text { disclosure, IT, investment policies, governance, asset management) for local and foreign participants. } \\
\text { - Further develop regulation and supervision relying on frequent and detailed exchange of information } \\
\text { with home pro-active supervisors. }\end{array}$ \\
\hline
\end{tabular}

What are the options available to small countries that meet the preconditions above mentioned? Above all, these countries need to integrate with global financial markets to develop contractual savings. This implies essentially to things: i) foreign ownership of intermediaries by reputable companies, possibly in the form of joint ventures; and ii) investment portfolios need to be properly diversified both locally and internationally as the implementation of credible and sound macroeconomic policies allow full opening of capital accounts. It is essential that in the process of integration countries with small financial systems use reputable foreign companies. The use of foreign companies can be done at the level of asset managers where funds are centrally collected and asset managers periodically bid for a license to manage assets. Alternatively, a menu of local and foreign mutual funds can be offered, allowing contributors to chose among the admitted mutual funds.

If integration with global financial markets is the key element for developing contractual savings, what are the tools available to countries with small financial market to achieve such integration? One way to answer this question is to look at the solutions adopted by other countries around the world in three key areas: i) institutional set-ups; ii) competition in the supply of pension services; and iii) fiduciary responsibilities.

As far as institutional set-ups are concerned, countries that have relied on closed, employer-based funds have generally witnessed a much larger number of funds than countries that have relied on open, non-employer funds. Employer funds avoid marketing costs and enjoy some economies of scope (and scale for large employers), but their performance depends on the solvency and integrity of employers as sponsors of pension plans. The record seems to be positive for the pension funds of large employers, but rather mixed for the plans of smaller firms. Countries that have relied on open, nonemployer funds have generally witnessed an inexorable consolidation process that 
resulted in the survival of a very small number of funds. A consolidated and highly concentrated pension system based on a small number of open funds enjoys economies of scale and may avoid excessive marketing costs. But such a system poses a serious policy challenge: how to ensure the continuing offer of competitive and efficient services. One solution to this dilemma could be to promote contestability by allowing employers to opt out from the open end system through the offer of employer-sponsored plans as well.

Economies of scale and scope are large in many areas of the supply of pension services like collection of contributions, data processing, maintenance of records, channeling of funds to asset managers and payment of benefits. Countries may not be able to successfully attract investment from highly reputable foreign companies in these area because of their small size. Whenever the small size of a country does not justify the sunk costs that characterizes some of the pensions services it might be necessary to allow foreign firms to centralize these services in a foreign location. Using centralized services in another country would reduce operating costs, both because of greater economies of scale and because of the location of such centralized services in countries with lower labor costs.

Countries with small financial systems may also have a small pool of human capital with the necessary expertise to manage pension funds. The countries need to contract reputable foreign companies, either to join local ventures or directly abroad. These companies would know how to operate efficiently systems with a large number of individual accounts. They would have experience in cross selling and exploiting both economies of scale and scope. They would have a well established expertise in asset management. They would be in a better position to resist government pressure and political interference in their day-to-day operations. They would also be better able to integrate their local operations with their global activities and, by implication, with global markets. In their activity, foreign institutions would train local staff and contribute to the improvement of the quality of skills. Finally, by attracting reputable foreign companies, reforming countries would reduce the costs of supervision which may take time to develop to meet adequate standards. The host country would have to rely on the providers' home country supervisory authorities; hence would need to enter into agreements with each of them to share information about the solvency of intermediaries.

Finally, countries with small financial systems need to ensure that the fiduciary responsibilities of fund managers are properly met. Contractual savings in developing countries are often seen as a captive source of funds for targeted development of specific industries, sectors, or markets. Contractual savings represent long term savings that should be managed in the best interest of beneficiaries and not used as development tools. They are not developmental tools. In this sense it is very important that the supply of trustee services and governance be maximized. Trustees need to be independent from political interference and this can often be achieved by allowing for competitive selection of pension funds management companies by individual contributors.

\section{REFERENCES}

[1] Aizenman, J., and P. E. Guidotti (1994) Capital Controls, Collection Costs and Domestic Public Debt. Journal of International Money and Finance, 13: 41-54. 
[2] Bartolini, L., and A. Drazen (1997) Capital-Account Liberalization as a Signal. American Economic Review, 87(1): 138-54.

[3] Bodie, Z. (1990) Pensions as Retirement Income Insurance. Journal of Economic Literature, 28(1): 28-49.

[4] Bossone, B., Honohan P., and M. Long (2001) Policy for Small Financial Systems. The World Bank, Financial Sector Discussion Paper No. 6.

[5] Catalan, M., Impavido G., and A. R. Musalem (2001) Contractual Savings or Stock Market Development: Which Leads? Journal of Applied Social Science Studies, 120(3): 445-87.

[6] Cerda, L., and G. Grandolini (1998) The 1997 Pension Reform in Mexico. The World Bank, Policy Research Working Paper Series, No. 1933.

[7] Davis, P. E. (1999) Investment of Mandatory Funded Pension Schemes. The Pension Institute, Birkbeck College.

[8] Dooley, M. P. (1996) A Survey of Academic Literature on Controls over International Capital Transactions. IMF Staff Papers, Vol. 43, No. 4: 639-687.

[9] Fontaine, J. A. (1997) Are There (Good) Macroeconomic Reasons for Limiting External Investments by Pension Funds? The Chilean Case. In Salvador ValdésPrieto Eds: The economics of pensions: Principles, policies, and international experience. Cambridge University Press.

[10] Glaessner, T., and S. Valdés-Prieto (1998) Pension Reform in Small Developing Countries. The World Bank, Policy Research Working Paper Series No. 1983.

[11] Iglesias, A., and R. J. Palacios (2000) Managing Public Pension Reserves. Part I: Evidence from the International Experience...The World Bank, Social Protection Discussion Paper No. 0003.

[12] Impavido, G., and A. R. Musalem (2000) Contractual Savings, Stock and Asset Markets. World Bank Policy Research Paper: 2490.

[13] Impavido, G., Musalem A. R., and T. Tressel (2001a) Contractual Savings and Firms' Financing Choices. World Bank Policy Research Paper No. 2612.

[14] Impavido, G., Musalem A. R., and T. Tressel (2001b) Contractual Savings Institutions and Banks' Stability and Efficiency. Mimeo.

[15] James, E., Ferrier G., Smalhout J., and D. Vittas (1999) Mutual Funds and Institutional Investments: What Is the Most Efficient Way to Set Up Individual Accounts in a Social Security System? The World Bank, Policy Research Working Paper Series, No. 2099.

[16] Kotlikoff, L. (1999) The World Bank's Approach and the Right Approach to Pension Reform. Mimeo.

[17] Laban, R. M., and F. B. Larrain (1997) Can a Liberalization of Capital Outflows Increase net Inflows? Journal of International Money and Finance, 16(3): 415:31. 
[18] Mauro, P. (1995) Corruption and Growth. The Quarterly Journal of Economics, Vol. 110(3): 681-712

[19] Missale, A., and O. J. Blanchard (1994), The Debt Burden and Debt Maturity. American Economic Review, 84(1), 309-19.

[20] Mitchell, O. S. (1998) Building an Environment for Pension Reform in Developing Countries. The World Bank, Social Protection Discussion Paper No 9803.

[21] Mitchell, O. S., and P. L. Hsin (1994) Public Pension Governance and Performance. NBER WP No. 4632.

[22] Obstfeld, M. (1986a) Capital Controls, the Dual Exchange Rate, and Devaluation. Journal of International Economics, Vol. 20:1-20.

[23] Obstfeld, M. (1986b) Rational and Self-Fulfilling Balance of Payments Crises. American Economic Review,. Vol. 76: 72-81.

[24] Obstfeld, M. (1994) The Logic of Currency Crises. Cahiers Economiques et Monetaires, No. 43: 189-213.

[25] Obstfeld, M. (1996) Models of Currency Crises with Self-Fulfilling Features. European Economic Review, Vol. 40: 1037-1047.

[26] Queisser, M. (1997) Pension Reform and Private Pension Funds in Peru and Colombia. The World Bank, Policy Research Working Paper Series, No. 1853.

[27] Queisser, M., and D. Vittas (2000) The Swiss Multi-Pillar Pension System: Triumph of Common Sense? The World Bank, Policy Research Working Paper Series, No. 2416.

[28] Reisen, H. (1995) Liberalizing Foreign Investments by Pension Funds: Pōsitiv̄ē and Normative Aspects. OECD Ageing Working Paper No. 5.3

[29] Reisen, H., and J. Williamson (2000) Pension Funds, Capital Controls, and Macroeconomic Stability. In Helmut Reisen Eds: Pensions, Savings, and Capital Flows : from Ageing to Emerging Markets. Cheltenham, UK. Edward Elgar

[30] Takaoshi, I., and A. O. Krueger (Eds) (2001) Regional and Global Capital Flows: Macroeconomic Causes and Consequences, East Asia Seminar on Economics Volume 10. The University of Chicago Press.

[31] Vittas, D. (1993) Swiss Chilanpore. The Way Forwards for Pension Reform? The World Bank, Policy Research Working Paper Series, No. 1093.

[32] Vittas, D. (1995) Sequencing Social Security, Pension, and Insurance Reform. The World Bank, Policy Research Working Paper Series: No. 1551.

[33] Vittas, D. (1998a) The Role of Non-Bank Financial Intermediaries. The World Bank, Policy Research Working Paper Series: No. 1892.

[34] Vittas, D. (1998b) Institutional Investors and Securities Markets: Which Comes First? The World Bank, Policy Research Working Paper Series, No. 2032. 
[35] Vittas, D. (2000) Pension Reform and Capital Market Development: "Feasibility" and "Impact" Preconditions. The World Bank, Policy Research Working Paper Series, No. 2414.

[36] Vittas, D., and M. Skully (1991) Overview of Contractual Savings Institutions. The World Bank, Policy Research Working Paper Series, No. 605.

[37] Von Gersdorff, H. (1997) Pension Reform in Bolivia: Innovative Solutions to Common Problems. The World Bank, Policy Research Working Paper Series, No. 1832. 



\begin{tabular}{|c|c|c|c|c|}
\hline & Title & Author & Date & for paper \\
\hline WPS2820 & $\begin{array}{l}\text { The Privatization of the Russian } \\
\text { Coal Industry: Policies and Processes } \\
\text { in the Transformation of a Major } \\
\text { Industry }\end{array}$ & $\begin{array}{l}\text { Igor Artemiev } \\
\text { Michael Haney }\end{array}$ & April 2002 & $\begin{array}{l}\text { V. Joseph } \\
32155\end{array}$ \\
\hline WPS2821 & $\begin{array}{l}\text { Income, Wealth, and Socialization } \\
\text { in Argentina: Provocative Responses } \\
\text { from Individuals }\end{array}$ & Daniel Lederman & April 2002 & $\begin{array}{l}\text { P. Soto } \\
37892\end{array}$ \\
\hline WPS2822 & $\begin{array}{l}\text { An Econometric Analysis of the } \\
\text { International Bank for Reconstruction } \\
\text { and Development's Creditworthiness }\end{array}$ & David Mckenzie & April 2002 & $\begin{array}{l}\text { C. Mendoza } \\
80599\end{array}$ \\
\hline WPS2823 & $\begin{array}{l}\text { Real Exchange Rate Uncertainty } \\
\text { and Private Investment in Developing } \\
\text { Countries }\end{array}$ & Luis Servén & April 2002 & $\begin{array}{l}\text { P. Solo } \\
37892\end{array}$ \\
\hline WPS2824 & $\begin{array}{l}\text { Trade Policy and Labor Services: } \\
\text { Final Status Options for the West } \\
\text { Bank and Gaza }\end{array}$ & Maurice Schiff & April 2002 & $\begin{array}{l}\text { P. Flewitt } \\
32724\end{array}$ \\
\hline WPS2825 & $\begin{array}{l}\text { Demand for Imports in Venezuela: } \\
\text { A Structural Time Series Approach }\end{array}$ & Mario A. Cuevas & April 2002 & $\begin{array}{l}\text { M. Geller } \\
85155\end{array}$ \\
\hline WPS2826 & $\begin{array}{l}\text { Potential GDP Growth in Venezuela: } \\
\text { A Structural Time Series Approach }\end{array}$ & Mario A. Cuevas & April 2002 & $\begin{array}{l}\text { M. Geller } \\
85155\end{array}$ \\
\hline WPS2827 & $\begin{array}{l}\text { Learning to Export: Evidence from } \\
\text { Moroccan Manufacturing }\end{array}$ & $\begin{array}{l}\text { Marcel Fafchamps } \\
\text { Said EI Hamine } \\
\text { Albert Zeufack }\end{array}$ & April 2002 & $\begin{array}{l}\text { E. Khine } \\
37471\end{array}$ \\
\hline WPS2828 & $\begin{array}{l}\text { Beyond Oaxaca-Blinder: Accounting } \\
\text { for Differences in Household Income } \\
\text { Distributions across Countries }\end{array}$ & $\begin{array}{l}\text { François Bourguignon } \\
\text { Francisco H. G. Ferreira } \\
\text { Phillippe G. Leite }\end{array}$ & April 2002 & $\begin{array}{l}\text { F. Bourguignon } \\
31056\end{array}$ \\
\hline WPS2829 & $\begin{array}{l}\text { The Spatial Distribution of Poverty } \\
\text { in Vietnam and the Potential for } \\
\text { Targeting }\end{array}$ & $\begin{array}{l}\text { Nicholas Minot } \\
\text { Bob Baulch }\end{array}$ & April 2002 & $\begin{array}{l}\text { R. Bonfield } \\
31248\end{array}$ \\
\hline WPS2830 & $\begin{array}{l}\text { Labor Market Implications of } \\
\text { Switching the Currency Peg in a } \\
\text { General Equilibrium Model for Lithuania }\end{array}$ & Lodovico Pizzati & April 2002 & $\begin{array}{l}\text { L. Pizzati } \\
32259\end{array}$ \\
\hline WPS2831 & $\begin{array}{l}\text { Health Outcomes in Poor Countries } \\
\text { and Policy Options: Empirical Findings } \\
\text { from Demographic and Health Surveys }\end{array}$ & Limin Wang & April 2002 & $\begin{array}{l}\text { L. Wang } \\
37596\end{array}$ \\
\hline WPS2832 & $\begin{array}{l}\text { Poverty and Survival Prospects } \\
\text { of Vietnamese Children under Doi Moi }\end{array}$ & $\begin{array}{l}\text { Adam Wagstaff } \\
\text { Nga Nguyet Nguyen }\end{array}$ & April 2002 & $\begin{array}{l}\text { H. Sladovich } \\
37698\end{array}$ \\
\hline WPS2833 & $\begin{array}{l}\text { School Choice, Student Performance, } \\
\text { and Teacher and School Characteristic } \\
\text { The Chilean Case }\end{array}$ & $\begin{array}{l}\text { Emiliana Vegas } \\
\text { cs: }\end{array}$ & April 2002 & $\begin{array}{l}\text { H. Sladovich } \\
37698\end{array}$ \\
\hline WPS2834 & $\begin{array}{l}\text { Investor Protection, Ownership, and } \\
\text { the Cost of Capital }\end{array}$ & $\begin{array}{l}\text { Charles P. Himmelberg } \\
\text { R. Glenn Hubbard } \\
\text { Inessa Love }\end{array}$ & April 2002 & $\begin{array}{l}\text { K. Labrie } \\
31001\end{array}$ \\
\hline
\end{tabular}


Policy Research Working Paper Series

Title

WPS2835 A Decade of Fiscal Transition

WPS2836 Ethnic Minority Development in Vietnam: A Socioeconomic

Perspective

WPS2837 Reform, Growth, and Poverty in Vietnam

WPS2838 Economic Mobility in Vietnam in the 1990s

WPS2839 Marketing Externalities and Market Development

WPS2840 Public Spending and Outcomes: Does Governance Matter?
Author

Asad Alam

Mark Sundberg

Bob Baulch

Truong Thi Kim Chuyen

Dominique Haughton

Jonathan Haughton

David Dollar

Paul Glewwe

Phong Nguyen

M. Shahe Emran

Forhad Shilpi

Andrew Sunil Rajkumar

Vinaya Swaroop
Date

May 2002

May 2002

May 2002

May 2002

May 2002

May 2002
Contact

for paper

A. Panton 85433

E. Khine 37471

E. Khine 37471

E. Khine 37471

F. Shilpi 87476

H. Sladovich 37698 